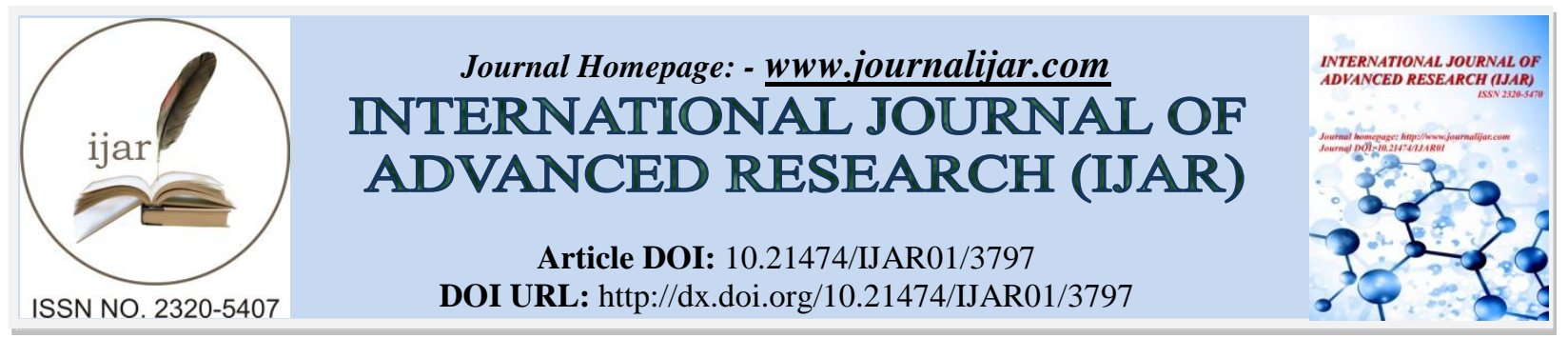

RESEARCH ARTICLE

\title{
STENOTROPHOMONAS MALTOPHILIA: A NOVEL PLANT GROWTH PROMOTER AND BIOCONTROL AGENT FROM MARINE ENVIRONMENT
}

\section{Nayomi John ${ }^{1}$ and M Thangavel ${ }^{2}$}

1. Research Scholar, Research and Development Centre, Bharathiar University, Coimbatore, India.

2. Professor \& Head, Department of Microbiology, Sree Narayana Guru College, Coimbatore, India.

\section{Manuscript Info}

Manuscript History

Received: 14 February 2017

Final Accepted: 05 March 2017

Published: April 2017

Key words:-

Phytohormone, Siderophore, Hydrogen Cyanide.

\begin{abstract}
Marine microorganisms have unique properties since they had adapted to extreme marine environmental conditions. In this study the in-vitro analysis of novel marine bacterial strains for plant growth promoting potentials like solubilisation of nutrient sources such as phosphate, potassium, zinc, production of phytohormones, organic acid and extracellular enzymes, nitrogen fixation ability, biocontrol activities like production of siderophore, 1-aminocyclopropane-1-carboxylate deaminase and hydrogen cyanide were carried out. Out of 19 morphologically distinct bacterial strains isolated, one predominant and most potent strain designated as MB9 was chosen for antifungal activity against phytopathogens and bioactive metabolite production. The bioactive secondary metabolites from the strain were extracted and identified using Gas Chromatography Mass Spectrometric method.
\end{abstract}

Copy Right, IJAR, 2017,. All rights reserved.

\section{Introduction:-}

The extreme complexity of marine environment, had led to microbial evolution. This evolution prompted the marine microorganisms to synthesize novel enzymes and secondary metabolites. These distinctive characteristics had attracted to explore in depth since the potential of marine microorganisms used in industry. The mechanisms by which plant growth promoting bacteria enhance plant growth were not fully understood [Abbas et al., (2009), Vessey (2003)] but, several mechanisms had suggested, including direct and indirect. The direct methods include production of phytohormone [Joo et al., (2004), Shaharoona et al., (2006)], provide stress resistance, fix atmospheric nitrogen [Nezarat and Gholami, (2009), Salanture et al (2006)], stimulates nutrient uptake and synthesis of enzymes like phosphatase [Bharathi et al., (2004), Rodriguez and Fraga, (1999)]. Indirect growth promotion occurs through the elimination of phytopathogens and other harmful microbes by the production of metabolites like hydrogen cyanide, siderophores and antibiotics [Bai et al., (2003), Chaiharn et al., (2008)]. This study was mainly attempted to isolate and screen marine sediment bacteria from Arabian Sea for plant growth promoting traits like production of phytohormones and organic acid, solubilization of essential nutrients like phosphate, potassium, and zinc, ability of nitrogen fixation, production of 1-aminocyclopropane-1-carboxylate deaminase and bioactive metabolites like siderophore, hydrogen cyanide, hydrolytic enzymes and antibiotics.

\section{Materials and Methods:-}

\section{Sample collection:-}

The marine sediment samples were collected from 15 different locations in Arabian Sea along the coast of Thiruvananthapuram, Kerala from $100 \mathrm{~m}$ depth. 
The samples were collected in different sterile containers and transported to the laboratory for further analysis. Isolation and enumeration of marine bacteria were performed on Zobell Marine Agar (Himedia) using standarad plate count method [Cappuccino and Sherman, (1992)].

\section{In- vitro screening of marine bacterial strains for Plant Growth Promoting potentials:-} Phosphate Solubilization Assay:-

Phosphate solubilizing activity was screened on Pikovskays Agar medium [Pikovaskya (1948)], for the clear zone formation around the bacterial colony after incubation at $30^{\circ} \mathrm{C}$ for $3-5$ days and it was expressed as phosphate solubilizing index (PSI) [Katznelson and Bose, (1959)].

Solubilization Index $(\mathrm{PSI})=\underline{\text { Colony diameter }+ \text { halo zone diameter }}$

\section{Colony diameter}

\section{Potassium Solubilization Assay:-}

The isolates were spot inoculated on to the modified Aleksandrov medium (Glucose, 5g; MgSO4.7H2O, 0.5 g; $\mathrm{CaCO}$, $0.1 \mathrm{~g}$; $\mathrm{FeCl} 3,0.006 \mathrm{~g}$; Ca3(PO4)2, $2.0 \mathrm{~g}$; Insoluble Mica powder, $3 \mathrm{~g}$, agar,20 g; D/W, 1000ml). The formation of halo zone around the colony after 3 days incubation at $30^{\circ} \mathrm{C}$ was considered as potassium solubilization ability [Hu et al., (2006)].

\section{Zinc Solubilization Assay:-}

All the isolates were inoculated on to the modified Pikovskaya medium containing $1 \%$ insoluble zinc compound (ZNO). The halo zone formation around the colony after incubation at $30^{\circ} \mathrm{C}$ for $48 \mathrm{hrs}$ indicates zinc solubilization [Pikovaskya (1948)].

\section{Production of Indole 3- Acetic Acid (Auxin):-}

In this method, tryptophan rich Luria Bertani (LB) broth was inoculated with the bacterial isolates. After 24hr incubation, $2 \mathrm{ml}$ culture supernatant was mixed with 2 drops of ortho phosphoric acid and $4 \mathrm{ml}$ of Salkowsky reagent (50 ml, of $35 \%$ sulphuric acid, $1 \mathrm{ml}$ of $0.5 \mathrm{M} \mathrm{FeCl} 3$ ) and incubated for $25 \mathrm{~min}$ at room temperature; development of pink colour indicates IAA production. The intensity of pink color developed was read at $535 \mathrm{~nm}$ using a UV-VIS spectrophotometer [Gordon and Weber, (1951)].

\section{Nitrogen Fixation Test:-}

The marine isolates were cultured onto nitrogen free Jensen's media and incubated for 2 or 3 days at $30^{\circ} \mathrm{C}$. Growth after incubation indicates that the ability of organisms to fix atmospheric nitrogen [Noori and Saud, (2012)].

\section{Organic Acid Production:-}

Bacterial cultures were grown in M9 agar medium with methyl red as $\mathrm{pH}$ indicator. The color of the media surrounding the organic acid producing strains changed from yellow to pink when $\mathrm{pH}$ changed below 5 due to acid production.

\section{Production of Extracellular Enzymes:-}

The marine bacterial isolates were subjected for the screening of extracellular enzymes production, namely protease, lipase, amylase, chitinase and DNAase using simple qualitative plate assay. The basal nutrient agar medium was prepared with different substrates of the tested enzymes at $1 \%$ concentration such as skim milk for protease, tween80 for lipase, starch for amylase, colloidal chitin for chitinase and DNA for DNAase. After 48 hrs incubation at room temperature, different visualization tests were performed to observe enzyme activity. A zone of clearance around the bacterial colony indicates positive protease, lipase and chitinase activity. For amylase test, iodine was used as indicator. Iodine reacts with the unhydrolyzed starch area to give a blue-black color. A clear zone around the colony at the site of hydrolyzed starch shows amylase production. For DNAase assay, plates were flooded with dilute HCI solution. HCL precipitates unhydrolyzed DNA and a clear zone of hydrolyzed DNA around the colony indicates DNAase activity [Ramesh and Mathivanan, (2009)]. Gelatinase test was performed by using the method described by [Blazevic and Ederer, (1975)]. It was done by inoculating the bacteria into gelatin tubes and incubated for 24-48hrs. If gelatinase was produced, the liquid medium fails to solidify upon refrigeration at $4{ }^{\circ} \mathrm{C}$ for about an hour after incubation at $24-48 \mathrm{hrs}$ at room temperature. 


\section{Biocontrol Assay:- \\ Production of Siderophore:-}

The marine bacterial isolates were subjected for the production of siderophore by using modified Chrome Azurol Sulfonate (CAS) assay [Alexander and Zuberer, (1991)]. To prepare blue or green agar 60.5mg of CAS is dissolved in $50 \mathrm{ml}$ of distilled water and mixed with $10 \mathrm{ml}$ of Iron solution $(1 \mathrm{Mm} \mathrm{FeCl} .6 \mathrm{H} 2 \mathrm{O}$ in $10 \mathrm{Mm} \mathrm{HCl})$. While constantly stirring, this solution is slowly added to $72.9 \mathrm{mg}$ of hexadecyltrimethyl ammonium bromide (HDTMA) dissolved in $40 \mathrm{ml}$ of water. The resultant dark blue/green liquid mixture was sterilized and added to sterile nutrient agar to make Chrome Azural S (CAS) agar. Spot inoculated and incubated at $30^{\circ} \mathrm{C}$ for $48-72 \mathrm{hrs}$. Development of yellow-orange halo around the growth is considered as positive for siderophore production.

\section{Production of Hydrogen Cyanide (HCN):-}

The bacteria were streaked on to nutrient agar amended with glycine $(4.4 \mathrm{~g} / \mathrm{l})$ plates. Whatman no.1 filter paper soaked in $2 \%$ sodium carbonate in $0.5 \%$ picric acid was placed at the inner surface of the lid of the Petri plate. Plates were sealed with parafilm and incubated at $30^{\circ} \mathrm{C}$ for 4 days. Development of orange to red color in the filter paper indicates HCN production [Lorck (1948)].

\section{Amino Cyclopropane1-Carboxylate (ACC) Deaminase Assay:-}

Qualitative assay of 1-AminoCyclopropane1-Carboxylate Deaminase was carried out using the method proposed by [Jacobson et al., (1994)].

\section{Biochemical characterization of bacterial strain:-}

The predominant and most potent bacterial strain MB9 was identified by using VITEK 2 compact systemBiomerieus, France automatic system. VITEK-2 system provides an automated, computer based method of species identifications, relies on advanced colorimetric technology, the measurement of light attenuation associated with each biochemical reactions in VITEK cards containing numerous wells to ensure test accuracy.

\section{In-vitro Antifungal Assay:- \\ Cross streak Method:-}

The antagonistic property of selected plant growth promoting marine bacterium was tested against different phytopathogens like Colleotrichum sp., Rhizoctonia solani., Curvularia sp., Diploidia sp., Fusarium sp., and Aspergillus sp., by using modified method of [Gupta et al., (2001)]. Agar blocks of 5 day old culture of test pathogens were placed in the centre of Tryptic Soy Agar (TSA). A loopful of $24 \mathrm{hr}$ old culture of bacterial strain was then streaked on either sides of pathogen disc at a distance of $2 \mathrm{~cm}$ apart. Control plates with the fungal pathogens alone were inoculated centrally on TSA plates. After 5 days incubation at $25 \pm 1^{\circ} \mathrm{C}$, inhibition of the fungal growth was measured. Percentage inhibition of mycelial growth was calculated using the following formula $\%$ of inhibition $=(\mathrm{C}-\mathrm{T}) / \mathrm{C} \times 100$, Where, $\mathrm{C}$ and $\mathrm{T}$ represent the growth of fungus in control plate and treatment plate respectively.

\section{Production of Secondary Metabolite:-}

Tryptic digest broth was prepared with $2 \% \mathrm{Nacl}$ in conical flasks. The selected bacterial strain was inoculated into the sterile broth. Then the flasks were kept in the shaking incubator for 3 days at 180rpm. After the incubation secondary metabolite was extracted.

\section{Extraction of Secondary Metabolite by Solvent Extraction Method:-}

After the production of secondary metabolites, the broth was aseptically transferred to sterile centrifuge tubes and centrifuged at 10,000 rpm for $15 \mathrm{mins}$. The supernatant was collected in sterile conical flask and the pellet was discarded. The supernatant was transferred to sterile separating funnel and mixed with ethyl acetate in the ratio 1:1 (supernatant: ethyl acetate). Then the mixture in the separating funnel was shaked continuously for 15mins. After $15 \mathrm{mins}$, keep the separating funnel undisturbed for $10-15 \mathrm{mins}$. Three layers were formed and the middle layer containing metabolite was removed in to a sterile petri plate. The structure of antifungal metabolite was established by the study of Gas Chromatography- mass spectrometry, (MS) [Uzair et al (2006)].

\section{Results and Discussion:-}

19 Morphologically distinct bacterial strains were selected (designated as MB1-MB19) and screened for its plant growth promoting potentials. Among the 19 isolates, 15 shows phosphate solubilization, auxin and organic acid 
production, 10 shows nitrogen fixation ability, 6 shows zinc solubilization, ACC Deaminase and hydrogen cyanide production, 13 shows siderophore production, 12 shows potassium solubilization (Table 1). The extracellular enzyme production was expressed in (Table 2). The most potent and predominant strain MB9 shows highest activity in all plant growth promoting traits. This potent strain was identified as Stenotrophomonas maltophilia by automated VITEK 2 compact system (Table 3). This bacterium was selected for biocontrol assay against fungal phytopathogens and further characterization, and it shows good antifungal activity (Table 4). Based on the result obtained from Gas Chromatography Mass Spectrometric method (GCMS), the active metabolite that mediates the broad-spectrum antifungal potential of Stenotrophomonas maltophilia has been identified as Dodecanoic acid.

Table 1:- Plant Growth Promoting Potentials.

\begin{tabular}{|c|c|c|c|c|c|c|c|c|c|c|}
\hline \multirow[t]{2}{*}{ No } & \multirow{2}{*}{$\begin{array}{l}\text { Marine } \\
\text { Isolates }\end{array}$} & \multicolumn{9}{|c|}{ Plant Growth Promoting Traits } \\
\hline & & $\begin{array}{c}\text { Phospha } \\
\text { te } \\
\text { Solubili } \\
\text { zation } \\
\text { Index } \\
\text { ( PSI) }\end{array}$ & $\begin{array}{c}\text { IAA } \\
\text { mg } \\
\mathrm{L}^{-1}\end{array}$ & $\begin{array}{l}\text { Nitro } \\
\text { gen } \\
\text { Fixat } \\
\text { ion }\end{array}$ & $\begin{array}{l}\text { Pottassi } \\
\text { um } \\
\text { solubili } \\
\text { zation }\end{array}$ & $\begin{array}{c}\text { Zinc } \\
\text { Solubiliz } \\
\text { ation }\end{array}$ & $\begin{array}{c}\text { ACC } \\
\text { Deaminase }\end{array}$ & $\mathrm{HCN}$ & $\begin{array}{l}\text { Sideroph } \\
\text { ore } \\
\text { Producti } \\
\text { on }\end{array}$ & $\begin{array}{c}\text { Organic } \\
\text { Acid } \\
\text { Production }\end{array}$ \\
\hline 1 & MB1 & $\begin{array}{c}2.25 \pm \\
0.05\end{array}$ & 2.152 & ++ & + & + & - & + & + & ++ \\
\hline 2 & MB2 & $\begin{array}{c}2.66 \pm \\
1.15\end{array}$ & - & - & + & - & - & - & - & ++ \\
\hline 3 & MB3 & - & 0.562 & - & - & - & - & - & + & - \\
\hline 4 & MB4 & $3.5 \pm 0.3$ & 1.061 & - & - & - & - & - & - & +++ \\
\hline 5 & MB5 & $\begin{array}{l}1.3 \pm \\
0.17\end{array}$ & 2.824 & ++ & + & - & + & + & + & + \\
\hline 6 & MB6 & $\begin{array}{c}2.76 \pm \\
0.15\end{array}$ & 1.623 & + & + & - & - & - & + & ++ \\
\hline 7 & MB7 & - & 0.741 & + & - & - & + & - & + & - \\
\hline 8 & MB8 & $\begin{array}{c}1.16 \pm \\
0.15\end{array}$ & 1.025 & + & + & - & - & - & - & + \\
\hline 9 & MB9 & $\begin{array}{l}4.6 \pm \\
0.57\end{array}$ & 5.341 & ++ & +++ & ++ & +++ & ++ & +++ & +++ \\
\hline 10 & MB10 & $\begin{array}{c}2.43 \pm \\
0.05\end{array}$ & 2.215 & - & + & - & - & - & - & ++ \\
\hline 11 & MB11 & $\begin{array}{c}2.53 \pm \\
0.05\end{array}$ & - & + & + & - & + & + & + & ++ \\
\hline 12 & MB12 & - & - & + & - & - & - & - & + & - \\
\hline 13 & MB13 & $\begin{array}{c}2.56 \pm \\
0.15\end{array}$ & 3.721 & - & + & ++ & - & + & + & ++ \\
\hline 14 & MB14 & $1.2 \pm 0.1$ & 2.532 & - & + & - & - & - & - & + \\
\hline 15 & MB15 & $\begin{array}{c}2.86 \pm \\
0.38 \\
\end{array}$ & 3.942 & ++ & + & + & + & + & ++ & ++ \\
\hline 16 & MB16 & $\begin{array}{l}3.6 \pm \\
0.36\end{array}$ & $\begin{array}{c}0.922 \\
8\end{array}$ & - & + & + & - & - & + & +++ \\
\hline 17 & MB17 & - & - & - & - & + & - & - & - & - \\
\hline 18 & MB18 & $\begin{array}{c}1.46 \pm \\
0.51\end{array}$ & 1.932 & + & - & - & + & + & + & + \\
\hline 19 & MB19 & $\begin{array}{c}2.73 \pm \\
0.2\end{array}$ & 0.795 & - & - & - & - & - & + & ++ \\
\hline
\end{tabular}

PSI Values are the mean of triplicates with standard error

- = No Activity, + = Weak Activity, ++ = Medium Activity, +++ = High Activity 
Table 2:- Production of Extracellular Enzymes.

\begin{tabular}{|c|c|c|c|c|c|c|}
\hline \multirow{2}{*}{$\begin{array}{c}\text { Bacterial } \\
\text { Strains }\end{array}$} & \multicolumn{6}{|c|}{ Extracellular Enzymes } \\
\hline & Amylase & Protease & Lipase & Gelatinase & Chitinase & DNAase \\
\hline MB1 & - & + & - & + & - & - \\
\hline MB2 & + & + & + & + & - & + \\
\hline MB3 & + & - & - & - & + & - \\
\hline MB4 & + & + & + & + & + & + \\
\hline MB5 & + & + & - & + & - & - \\
\hline MB6 & + & - & + & - & + & + \\
\hline MB7 & - & + & + & + & - & - \\
\hline MB8 & + & + & - & + & - & - \\
\hline MB9 & - & + & + & + & + & + \\
\hline MB10 & + & - & + & - & + & - \\
\hline MB11 & + & + & + & + & + & - \\
\hline MB12 & - & + & + & - & - & + \\
\hline MB13 & - & - & + & - & - & - \\
\hline MB14 & + & + & - & + & + & + \\
\hline MB15 & + & + & + & + & - & + \\
\hline MB16 & + & + & - & + & + & - \\
\hline MB17 & - & + & + & - & - & - \\
\hline MB18 & + & + & - & - & + & + \\
\hline MB19 & + & - & + & + & - & + \\
\hline
\end{tabular}

- = No Production, $+=$ Production

Table 3:- Biochemical Characteristics of Strain MB9- Stenotrophomonas Maltophilia.

\begin{tabular}{|c|c|c|c|c|c|c|c|c|}
\hline 1 & $\begin{array}{l}\text { Ala-Phe-Pro- } \\
\text { ARYLAMIDASE } \\
\text { (APPA) }\end{array}$ & + & 12 & $\begin{array}{c}\text { ALPHA- } \\
\text { GALACTOSIDASE } \\
\text { (AGAL) }\end{array}$ & - & 23 & $\begin{array}{l}\text { BETA-Alanine arylamidase } \\
\text { pNA (BAlap) }\end{array}$ & - \\
\hline 2 & ADONITOL (ADO) & - & 13 & PHOSPHATASE (PHOS) & + & 24 & $\begin{array}{c}\text { L-Proline } \\
\text { ARYLAMIDASE (ProA) }\end{array}$ & + \\
\hline 3 & $\begin{array}{l}\text { L-Pyrrolydonyl- } \\
\text { ARYLAMIDASE } \\
\text { (PyrA) }\end{array}$ & - & 14 & $\begin{array}{c}\text { Glycine ARYLAMIDASE } \\
\text { (GlyA) }\end{array}$ & - & 25 & LIPASE (LIP) & + \\
\hline 4 & L-ARABITOL (IARL) & - & 15 & $\begin{array}{c}\text { ORNITHINE } \\
\text { DECARBOXYLASE } \\
\text { (ODC) }\end{array}$ & - & 26 & PALATINOSE (PLE) & - \\
\hline 5 & $\begin{array}{l}\text { D-CELLOBIOSE } \\
(\mathrm{dCEL})\end{array}$ & - & 16 & $\begin{array}{c}\text { LYSINE } \\
\text { DECARBOXYLASE } \\
\text { (LDC) }\end{array}$ & - & 27 & $\begin{array}{c}\text { Tryosine ARYLAMIDASE } \\
\text { (TyrA) }\end{array}$ & - \\
\hline 6 & $\begin{array}{c}\text { BETA- } \\
\text { GALACTOSIDASE } \\
\text { (BGAL) }\end{array}$ & - & 17 & $\begin{array}{c}\text { L-HISTIDINE } \\
\text { assimilation (IHISa) }\end{array}$ & - & 28 & UREASE (URE) & - \\
\hline 7 & $\begin{array}{c}\text { H2S PRODUCTION } \\
(\mathrm{H} 2 \mathrm{~S})\end{array}$ & - & 18 & $\begin{array}{l}\text { BETA-GLUCOSIDASE } \\
(\mathrm{BGLU})\end{array}$ & + & 29 & COURMARATE (CMT) & - \\
\hline 8 & $\begin{array}{c}\text { BETA-N-ACETYL- } \\
\text { GLUCOSAMINIDASE } \\
\text { (BNAG) }\end{array}$ & + & 19 & D-MALTOSE (dMAL) & - & 30 & $\begin{array}{c}\text { BETA- } \\
\text { GLUCURONIDASE } \\
\text { (BGUR) }\end{array}$ & - \\
\hline 9 & $\begin{array}{c}\text { Glutamyl } \\
\text { ArylamidasepNA } \\
\text { (AGLTp) }\end{array}$ & - & 20 & D-MANNITOL (dMAN) & - & 31 & $\begin{array}{c}\text { Glu-Gly-Arg- } \\
\text { ARYLAMIDASE (GGAA) }\end{array}$ & + \\
\hline 10 & D-GLUCOSE (dGLU) & - & 21 & D-MANNOSE (dMNE) & - & 32 & $\begin{array}{l}\text { L-MALATE assimilation } \\
\text { (IMLTa) }\end{array}$ & - \\
\hline 11 & $\begin{array}{l}\text { FERMENTATION } \\
\text { GLUCOSE (OFF) }\end{array}$ & - & 22 & $\begin{array}{c}\text { BETA-XYLOSIDASE } \\
\text { (BXYL) }\end{array}$ & - & 33 & ELLMAN (ELLM) & - \\
\hline
\end{tabular}




\begin{tabular}{|c|c|c|c|c|c|}
\hline $\mathbf{3 4}$ & $\begin{array}{c}\text { L-LACTATE } \\
\text { assimilation (ILATa) }\end{array}$ & - & $\mathbf{4 0}$ & MALONATE (MNT) & - \\
\hline $\mathbf{3 5}$ & D-SORBITOL (dSOR) & - & $\mathbf{4 1}$ & $\begin{array}{c}\text { 5-KETO-D- } \\
\text { GLUCONATE (5KG) }\end{array}$ & - \\
\hline $\mathbf{3 6}$ & SACCHAROSE (SAC) & - & $\mathbf{4 2}$ & $\begin{array}{c}\text { L-LACTATE } \\
\text { alkalinization (ILATk) }\end{array}$ & + \\
\hline $\mathbf{3 7}$ & $\begin{array}{c}\text { D-TAGATOSE (dTAG) } \\
\mathbf{3 8}\end{array}$ & - & $\mathbf{4 3}$ & $\begin{array}{c}\text { ALPHA-GLUCOSIDASE } \\
\text { (AGLU) }\end{array}$ & + \\
\hline $\mathbf{3 9}$ & $\begin{array}{c}\text { CITRATE(SODIUM) } \\
\text { (dTRE) } \\
\text { (CIT) }\end{array}$ & + & $\mathbf{4 5}$ & $\begin{array}{c}\text { SUCCINATE } \\
\text { alkalinization (SUCT) }\end{array}$ & + \\
\hline & $\begin{array}{c}\text { GALACTOSACETYL- } \\
\text { (NAGA) }\end{array}$ & - \\
\hline
\end{tabular}

- = Negative Reaction, $+=$ Positive Reaction

Table 4:- Antagonistic Assay of the Most Potent Strain MB9 against Phytopathogenic Fungi.

\begin{tabular}{|c|c|c|c|}
\hline \multicolumn{2}{|c|}{ Fungal Strains } & \multicolumn{2}{|c|}{ Antagonism Assay } \\
\hline & & Radial Growth (Mm) & Percentage Inhibition (\%) Zone \\
\hline \multirow[b]{2}{*}{ Rhizoctonia solani } & Control & 48.0 & 0 \\
\hline & Test & 18.3 & 61.8 \\
\hline \multirow[b]{2}{*}{ Fusarium oxysporum } & Control & 45.0 & 0 \\
\hline & Test & 15.0 & 66.6 \\
\hline \multirow[b]{2}{*}{ Colleotrichum sp } & Control & 51.0 & 0 \\
\hline & Test & 10.2 & 80.0 \\
\hline \multirow[b]{2}{*}{ Diploidia $\mathrm{sp}$} & Control & 40.4 & 0 \\
\hline & Test & 18.3 & 54.7 \\
\hline \multirow[b]{2}{*}{ Aspergillus niger } & Control & 54.6 & 0 \\
\hline & Test & 12.2 & 77.7 \\
\hline \multirow[b]{2}{*}{ Curvularia sp } & Control & 43.7 & 0 \\
\hline & Test & 15.3 & 64.9 \\
\hline
\end{tabular}




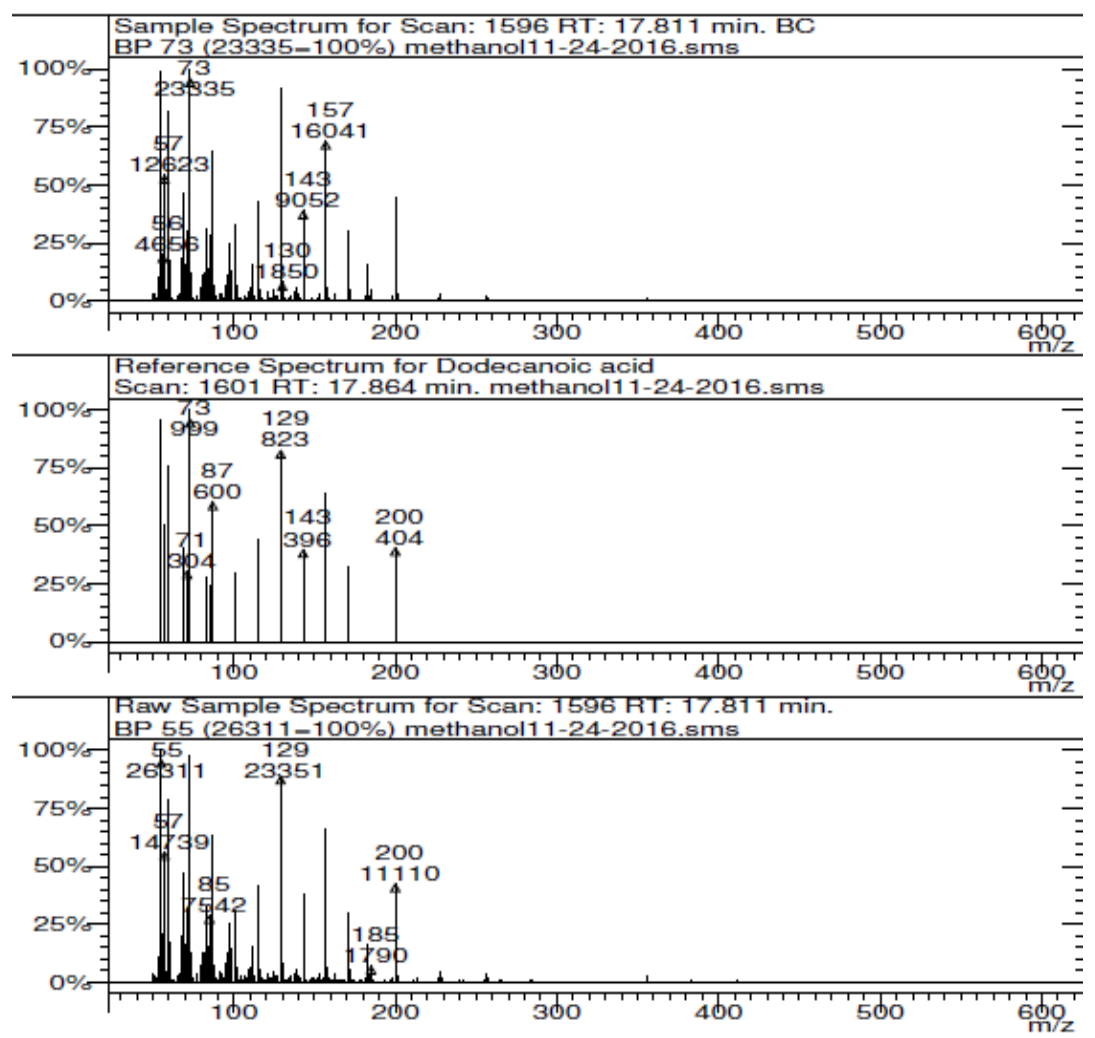

Fig.1:- Mass Spectrum of Dodecanoic Acid (Metabolite produced by Stenotrophomonas maltophilia).<smiles>CCCCCCCCCCCC(=O)O</smiles>

Fig. 2:- Molecular Stuucture of the Dodecanoic Acid, Molecular Weight 200.32, Molecular formula: $\mathrm{C}_{12} \mathrm{H}_{24} \mathrm{O}_{2}$

The presence of major plant growth promoting traits such as Indole Acetic Acid, phosphate solubilization, nitrogen fixation, siderophores and chitinase activities in the potent strain Stenotrophomonas maltophilia, may enhance its biofertilizer potential as well as biocontrol efficiency against different fungal phytopathogens. Previous study reported that the solubilization of iron by microbial siderophores and solubilization of phosphorous because of phosphatase were found to significantly increase crop yield [Brown (1974), Kloepper et al., (1988), Glick (1995)]. It has been reported that the production of Indole Acetic Acid by plant beneficial bacteria enhances the development of host plant root system and thus helps in the growth of crop plants [Patten and Glick, (2002), Suresh et al (2010)].

\section{Conclusion:-}

The results obtained through this study suggested that the potential use of Stenotrophomonas maltophilia as an effective biocontrol agent that promoting plant growth with reduced incidence of diseases. Further investigation on the type of antimicrobial components and field experiments on Stenotrophomonas maltophilia needed to introduce eco-friendly plant growth promoting and antifungal agents instead of hazardous chemicals.

\section{References:-}

1. Abbas ZP, Saleh RN, Rahmani AH, Khavazi K,Soltani A, Shoary-Nejati AR, Mohammad M (2009). Plant growth promoting activites of fluorescent pseudomonads isolated from the Iranian soil. Acta Physiol Plant.1738-009-0405-1.

2. Alexander, D.B. and D.A. Zuberer. 1991. Use of chrome azurol S reagents to evaluate siderophore production by rhizosphere bacteria. Biol. Fertil. Soils 2: 39-45.

3. Bai, Y., X. Zhou and D.L. Smith, 2003. Enhanced soybean plant growth resulting from coinoculation of Bacillus strains with Bradyrhizobium japonicum. Crop Sci., 43: 1774-1781. DOI:10.2135/CROPSCI2003.1774 
4. Bharathi, R., R. Vivekananthan, S. Harish, A.Ramanathan and R. Samiyappan, 2004. Rhizobacteria-based bioformulations for the management of fruit rot infection in chillies. Crop Prot., 23: 835-843.

5. Blazevic, D. J. and Ederer, G. M. (1975). Principles of Biochemical Tests in Diagnostic Microbiology, Wiley and Company, New York. pp.13 - 45.

6. Brown, M.E. (1974) Seed and root bacterization. Annual Review of Phytopathology 12, 181-197.

7. Cappuccino, J.C. and Sherman N, Microbiology(1992): A Laboratory Manual, 3 Edn, Benjamin/cummings Pub. Co. New York. 125-179.

8. Chaiharn M, Chunhaleuchanon S, Kozo A,Lumyong S (2008). Screening of rhizobacteria for their plant growth promoting activities. J.KMITL Sci. Tech., 8: 18-23.

9. Glick, B.R. (1995).The enhancement of plant growth promotion by free living bacteria. Canadian Journal of Microbiology 41, 109-117.

10. Gordon, A. S. and Weber, R. P. (1951). Colorimetric estimation of indole acetic acid. Pl Physiol $26: 192$ - 195.

11. Gupta, C. D., Dubey, R. C., Kang, S. C. and Maheshwari, D. K. (2001): Antibiotic mediated necrotrophic effect of Pseudomonas GRC2 against two fungal plant pathogens. Current Sci., 81: 91-94.

12. Hu X.F., Chen J. and Gu J.F., (2006). Two phosphate and potassium solubilizing bacteria isolated from Tiannu Mountain, Zhejiang, China. World Journal of Microbiology and Biotechnology, 22, 983-990.

13. Jacobson, C. B., J. J. Pasternak and B. R. Glick (1994). Partial purification and characterization of 1aminocyclopropane-1-carboxylate deaminase from the plant growth promoting rhizobacterium Pseudomonas putida GR12-2. Can. J. Microbiol.40: 1019-1025.

14. Joo GJ, Kim YM, Lee KIJ, Song S, Rhee IK (2004). Growth promotion of red pepper seedlings and the production of gibberellins by Bacillus cereus, Bacillus macroides, Bacillus pumilus. iotechnol. Letters. 26:487491.

15. Katznelson H and B. Bose (1959). Metabolic activity and phosphate-dissolving capability of bacterial isolates from wheat roots, rhizosphere, and nonrhizosphere soil. Can. J. Microbiol. 5:79-85.

16. Kloepper, J.W., Leong, J., Teintze, M. and Schroth, M.N. (1980) Enhanced plant growth by siderophores produced by plant growth promoting rhizobacteria. Nature 286, 885-886.

17. Lorck . H.,1948. Production of Hydrocyanic acid by bacteria. Plant physiol.1:142-146.

18. Nezarat S, Gholami A. Screening Plant Growth Promoting Rhizobacteria for Improving Seed Germination, Seedling Growth and Yield of Maize. Pakistan Journal of Biological Sciences, 2009; 12: 26-32.

19. Noori, M. S. S. and Saud, H. M. (2012). Potential plant growth-promoting activity of Pseudomonas sp isolated from paddy soil in Malaysia as biocontrol agent. Plant. Pathol. Microbiol., 3(2): 120.

20. Patten, C.L. and Glick, B.R. (2002) Role of Pseudomonas putida indoleacetic acid in development of the host plant root system. Applied and Environmental Microbiology 68, 3795-3801

21. Pikovaskya R.I., (1948). Mobilization of phosphorus in soil in connection with the vital activity of some microbial species. Microbiology, 7, 362-370.

22. Ramesh, S. and Mathivanan, N. (2009). Screening of marine actinomycetes isolated from the Bay of Bengal, India for antimicrobial activity and industrial enzymes. World J. Microbiol. Biotechnol. 25: 2103-2111.

23. Rodriguez H, Fraga R (1999). Phosphate solubilizing bacteria and their role in plant growth promotion. Biotecnology Advances. 17:319-339

24. Salanture A., A. Ozturk and S. Akten, (2006).Growth and yield response of spring wheat (Triticum aestivum L.) to inoculation with rhizobacteria. Plant. Soil. Environ. 52(3): 111-118.

25. Shaharoona, B., M. Arshad, Z.A. Zahir and A.Khalid, (2006). Performance of Pseudomonas spp.containing ACC-deaminase for improving growth and yield of maize (Zea mays L.) in the presence of nitrogenous fertilizer. Soil Biol.Biochem., 38: 2971-2975.

26. Suresh A, Pallavi P, Srinivas P, Kumar VP,Chandra SJ, Reddy SR. Plant growth promoting activities of fluorescent pseudomonads associated with some crop plants. African Journal of Microbiology Research, 2010; 4(14):1491-1494

27. Uzair B, Ahmed N, Ahmed V, Kousar F. A new antibacterial compound produced by indigenous marine bacteria; fermentation, isolation and biological activity. Nat Pro Res 2006, 20(14), 1326-1331

28. Vessey JK (2003). Plant growth promoting rhizobacteria as biofertilizers. Plant Soil 255: 571-586. 